\title{
Author Correction: Assessing data availability and research reproducibility in hydrology and water resources
}

\author{
James H. Stagge ${ }^{1,2}$, David E. Rosenberg ${ }^{1}$, Adel M. Abdallah ${ }^{1,3}$, Hadia Akbar $^{1}$, Nour A. Attallah ${ }^{1}$ \\ \& Ryan James ${ }^{1}$
}

Correction to: Scientific Data https://doi.org/10.1038/sdata.2019.30, published online 26 February 2019

In the original version of this Article the author of reference \#38 was incorrectly stated as Quinn, J. et al. This has been corrected to Xu, W. et al. in both the HTML and PDF versions.

(c) (i) Open Access This article is licensed under a Creative Commons Attribution 4.0 International cc) License, which permits use, sharing, adaptation, distribution and reproduction in any medium or format, as long as you give appropriate credit to the original author(s) and the source, provide a link to the Creative Commons license, and indicate if changes were made. The images or other third party material in this article are included in the article's Creative Commons license, unless indicated otherwise in a credit line to the material. If material is not included in the article's Creative Commons license and your intended use is not permitted by statutory regulation or exceeds the permitted use, you will need to obtain permission directly from the copyright holder. To view a copy of this license, visit http://creativecommons.org/licenses/by/4.0/.

(c) The Author(s) 2019

${ }^{1}$ Utah State University, Department of Civil and Environmental Engineering and Utah Water Research Laboratory, Logan, UT, 84321, USA. ${ }^{2}$ The Ohio State University, Department of Civil, Environmental and Geodetic Engineering, Columbus, OH, 43210, USA. ${ }^{3}$ The Western States Water Council, Salt Lake City, UT, 84107, USA. Correspondence and requests for materials should be addressed to J.H.S. (email: stagge.11@osu.edu) 